\title{
Drying Temperature Effect on Kernel Damage and Viability of Maize Dried in a Solar Biomass Hybrid Dryer
}

\author{
Joseph 0. Akowuah1 ${ }^{*}$, Dirk Maier ${ }^{2}$, George Opit ${ }^{3}$, Sam McNeill ${ }^{4}$, Paul Amstrong5, \\ Carlos Campabadal ${ }^{6}$, Kingsly Ambrose ${ }^{7}$, George Obeng-Akrofi ${ }^{1}$
}

\author{
${ }^{1}$ Department of Agricultural and Biosystems Engineering, Kwame Nkrumah University of Science and Technology, \\ Kumasi, Ghana \\ ${ }^{2}$ Iowa State University, Ames, USA \\ ${ }^{3}$ Oklahoma State University, Stillwater, USA \\ ${ }^{4}$ University of Kentucky, Lexington, USA \\ ${ }^{5}$ Center for Grain and Animal Health Research, USDA-ARS, Manhattan, USA \\ ${ }^{6}$ Kansas State University, Manhattan, USA \\ ${ }^{7}$ Purdue University, West Lafayette, USA \\ Email: ^akowuahjoe@yahoo.co.uk
}

How to cite this paper: Akowuah, J.O. Maier, D., Opit, G., McNeill, S., Amstrong, P., Campabadal, C., Ambrose, K. and Obeng-Akrofi, G. (2018) Drying Temperature Effect on Kernel Damage and Viability of Maize Dried in a Solar Biomass Hybrid Dryer. Open Journal of Applied Sciences, 8 , 506-517.

https://doi.org/10.4236/ojapps.2018.811041

Received: October 31, 2018

Accepted: November 23, 2018

Published: November 26, 2018

Copyright (c) 2018 by authors and Scientific Research Publishing Inc. This work is licensed under the Creative Commons Attribution International License (CC BY 4.0).

http://creativecommons.org/licenses/by/4.0/ (c) (7) Open Access

\begin{abstract}
Though several maize varieties have been developed and introduced over the years in Ghana, farmers still face challenges of access to quality seed maize. Among the major constraint is lack of proper drying systems to guarantee quality of seed produced. As in most parts of Africa, drying of maize in the open, on bare ground along shoulders of roads is still a common practice in Ghana. In this study, a 5-tonne capacity hybrid solar biomass dryer was developed for drying maize for seed and food/feed in Ghana. Effect of air temperature in the dryer on the physiological quality and germination of maize kernels was investigated. Maize grains were dried in the open sun simulating farmers practice and using the dryer at 4 varying levels (L1, L2, L3 and L4) with corresponding heights $(0.6 \mathrm{~m}, 1.2 \mathrm{~m}, 1.8 \mathrm{~m}$ and $2.4 \mathrm{~m}$, respectively) from the ground. Harvested maize at $22.8 \%$ moisture content was dried at the varying levels until reaching the final desired moisture content of $12.8 \% \pm 0.2 \%$ $(\mathrm{wb})$. Results showed that, air temperatures in the dryer increased in accordance with height with lowest mean temperature of $44.4^{\circ} \mathrm{C} \pm 4.6^{\circ} \mathrm{C}$ recorded at $\mathrm{L} 1$ and mean maximum of $52.8^{\circ} \mathrm{C} \pm 5.4^{\circ} \mathrm{C}$ at L4. Drying temperatures recorded at L1 - L3 and ambient had no significant effect $(\mathrm{p}<0.05)$ on kernel damage and viability. Drying conditions at L1-L3 were considered optimum $\left(<50^{\circ} \mathrm{C}\right)$ for kernel drying compared to the topmost tray, L4. Kernel stress crack index (multiple and checked) was therefore reduced on average by $14 \%$
\end{abstract}


while kernel germination increased by $33 \%$. This satisfies the dryer's potential to be used for commercial drying of maize grains for seed production for smallholder farmers in Ghana.

\section{Keywords}

Solar Biomass Hybrid Dryer, Drying Temperature, Maize Moisture, Stress Crack, Germination

\section{Introduction}

Maize (Zea mays) is an important cereal food crop extensively cultivated worldwide for food and as livestock fodder. In Ghana and sub-Sahara Africa, maize is the most important cereal crop produced and is also the most widely consumed staple food. The production of maize in Ghana is dominated predominantly by smallholder, resource poor farmers mainly under traditional production practices and rain-fed conditions resulting in yields well below attainable levels [1]. Maize yields in Ghana average approximately 1.9 metric tonnes per hectare, however, achievable yields as high as 6 metric tonnes per hectare are possible, if farmers use improved seeds, fertilizer, mechanization and irrigation [2]. However, availability of quality improved seeds is one of the major challenges faced by smallholder farmers in Ghana resulting in over reliance on their own seed stock from their previous harvest for the next production. This is corroborated by [3] who reported that, over $80 \%$ of smallholder farmers in Africa mainly get their seeds from the informal seed system which include farmers' own saved seeds, seed exchanges between farmers or buying from the local grain market.

Maize at harvest normally has high moisture content which is considered inappropriate for safe storage as grain for seed or feed. Under such situations, there is clearly a need for a reduction in moisture to preserve the physiological quality of seeds for at least eight months, impeding possible chemical and physical changes that may come about during storage up to sale or use of the seeds [4]. Drying maize after harvest from high moisture content (20\% - 30\%) to low safe storage moisture content $(12 \%-14 \%)$ is therefore necessary to ensure storability and preservation of maize grains of seed lots in warm and humid countries like Ghana.

Post-harvest activities such as drying and storage are among the key areas along the maize value chain that is of critical importance to smallholder farmers/traders in Africa [5]. However, during traditional drying of maize, farmers leave the crop to dry in the field or in the open sun next to farmers' homes or along roadsides, either on bare ground or on tarpaulins. This is considered unhygienic and can be detrimental to the quality of the dried maize grain. Additionally, during periods of unfavorable weather conditions, especially, in the major production season when harvest coincides with the raining season, drying can take up to 10 days before a safe storage moisture content of $12 \%-14 \%$ is 
reached. Inadequate drying especially among smallholder farmers during such occasion poses serious threats to food safety and security in Ghana. Drying under such situations create favourable conditions for fungal growth and insect damage during storage [6] leading to substantial loss of grains for seed or food. A significant percentage of post-harvest losses and aflatoxin contamination in maize and other foodstuffs can therefore be attributed to improper and/or inefficient drying [7] particularly during such periods in very humid countries like Ghana where most farmers rely on the traditional open-sun drying method. Nevertheless, the few installed heated air mechanical dryers for maize seed drying is also not desirable by most smallholder farmers in Ghana due to high drying charges and excessive drying air temperatures of $70^{\circ} \mathrm{C}-100^{\circ} \mathrm{C}$. This poses severe constraints on crops such as beans with recommended drying temperature $\left(35^{\circ} \mathrm{C}\right)$, rice $\left(45^{\circ} \mathrm{C}\right)$, and all grains $\left(45^{\circ} \mathrm{C}\right)$ if they are to be used for seed [8].

The viability of grain can therefore be directly linked to the drying temperature attained during the drying process. Seed embryos could be killed by extremely high temperatures and therefore low temperature drying schemes must be used. Seed grain may be dried in any type of dryer provided it is operated at a low temperature and preferably with high flow rates than generally used [8]. [9], reported maximum average germination percentage and viability of dried paddy seed of $86 \%$ and $98 \%$, respectively, after drying paddy seeds at $44^{\circ} \mathrm{C}$ in a hybrid solar drier. Rapid drying under high temperatures in mechanical drying systems often results in stress cracks, reduction of milling quality of grains, discolouration and reduced germination potential [10].

Conventional solar dryers may be a solution to these challenges but due to the high weather dependency, usage is limited during rainy periods, cloudy weather conditions and at night. Due to this, the commercialization of solar dryers has generally not been successful leading to limited or non-adoption of such systems by farmers in Ghana [11]. To overcome the restrictions of the conventional type solar dryers, a hybrid solar dryer with heat energy from solar radiations and fossil fuel or biomass is required for drying agricultural products [12]. Integration of these energy sources can lead to a reduction of drying time and have positive effects on quality of the product. This is corroborated in a study that reported maize grain dried using a biomass-heated natural convection dryer did not significantly reduce the kernel viability [13]. In this study, the performance of a 5-tonne capacity solar biomass hybriddryer (SBHD) that integrates both solar and biomass energy for commercial drying of maize for seed production was investigated. Specifically, the effect of drying temperature on stress cracks of grains dried in the dryer and viability were determined.

\section{Materials and Methods}

The experiment was conducted in January, 2017 using a 5-T capacity SBH dryer purposely constructed for a commercial seed maize distributor at Wenchi in the Brong Ahafo Region of Ghana. 


\subsection{Dryer Description}

Figure 1 shows the schematic and constructed views of the 5-tonne capacity SBHD at the site. The SBHD is based on a greenhouse structure design with an overall dimension of $10.7 \times 6.5 \times 3.3 \mathrm{~m}$. It is partitioned into three internal drying sections i.e., the Right Section (RS), Left Section (LS) and a Middle Section (MS). Each of these stations have four levels of drying shelves/racks. The drying shelves are arranged from bottom to top in order of Level 1 (L1), L2, L3 and L4with corresponding heights $(0.6 \mathrm{~m}, 1.2 \mathrm{~m}, 1.8 \mathrm{~m}$ and $2.4 \mathrm{~m})$ from the ground, respectively. The dryer is coupled with a biomass burner enclosed with a crossflow type heat exchanger to raise the temperature of ambient air that is blown into the drying chamber using a $0.374-\mathrm{kW}$ axial-flow fan that draws in drying air through the heat exchangers and passes it through the drying beds. The SBHD was test-run during the minor maize production season under load conditions during the month of January 2017 at the installed location.

\subsection{Experimental Procedure and Setup}

To assess the performance of the SBHD, white shelled maize at $22.8 \%$ moisture content (wet basis) was obtained from a local farmer and dried in the dryer and in the open sun. Drying occurred using experimental cages $(0.3 \mathrm{~m} \times 0.3 \mathrm{~m} \times 0.05$ $\mathrm{m})$. Each cage was filled with maize seed samples weighing $1 \mathrm{~kg}$ and were replicated three times at each level within the dryer. A control set-up of equal maize seeds $(1 \mathrm{~kg})$, in triplicate was also dried in the open sun as practiced by most rural farmers in the area. The experimental trays containing the maize samples were taken out every hour and weighed to monitor the moisture reduction in the maize samples. The moisture content at the $\mathrm{i}^{\text {th }}$ time during the drying period was calculated using Equation (1) until the required final moisture content was attained.

$$
\text { Moisture content (\%); } M C_{i}=\left(1-W_{o} \frac{1-M_{o}}{W_{i}}\right) \times 100
$$

$M C_{i}=$ moisture content at $i^{\text {th }}$ time (\%);

$M_{o}=$ initial moisture content in decimal;

$W_{o}=$ initial weight of samples in gram (g);

$W_{i}=$ weight of samples at $I^{\text {th }}$ time in grams $(\mathrm{g})$.
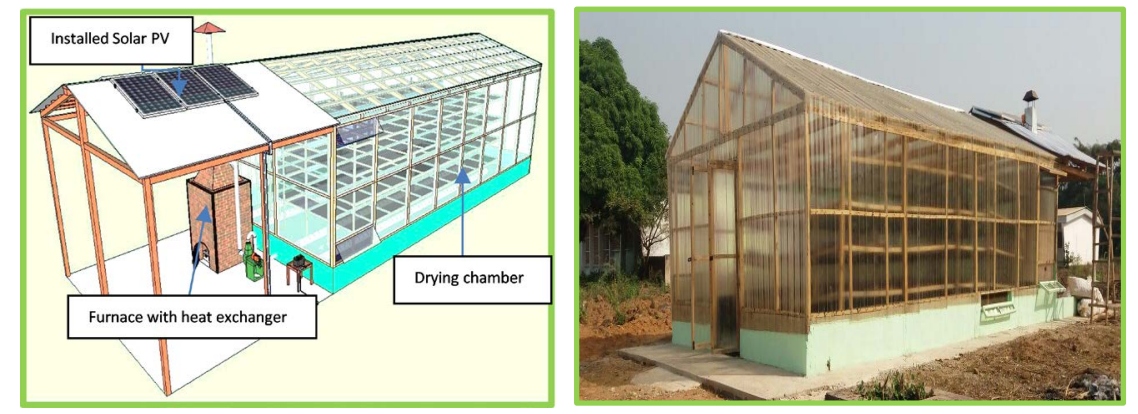

Figure 1. Solar Biomass Hybrid Dryer; schematic view (left) and constructed view (right). 
The drying process started at 09:50 am and continued for a period of seven (7) hours. During this period, TinyTagTGP-4017 data loggers (Gemini Data Loggers, Chichester, UK) were installed near the experimental cages to monitor and register variations in temperature and relative humidity in the drying environment. Five data loggers were positioned, as shown in Figure 2, at each of the four levels and the average used to represent the drying conditions at each level. Drying conditions in the dryer were compared with the ambient conditions.

\subsection{Germination Test}

The germination test was carried out in accordance with the criteria established in the Rules for testing seed [14]. Four sub-samples each of 100-seedsfor each drying level and a similar set-up for grains dried in the open sun were randomly selected and planted in germination trays filled with soil fetched from a river bank. The setup was kept under room temperature conditions. Emergence counts started from the $5^{\text {th }}$ day after planting and continued on the $6^{\text {th }}$ and $7^{\text {th }}$ days. The percentage of normal seedlings was calculated eight days after the test was set up. The percentage germinated seeds were calculated using Equation (2) as reported by [15].

$$
\% \text { Germination }=\frac{\text { number of seeds germinated }}{\text { number of seeds set for germination }} \times 100 \%
$$

\subsection{Stress Crack Test}

Maize grains were selected by random sampling from each station per layer of dried grains. For each sample, 100 seeds free from insect attack were counted and analysed for stress cracks. The samples were placed on a light box and checked for single, double, multiple or no cracks. The stress crack index (SCI) for each sample was determined using Equation (3) as proposed by [16].

$$
\mathrm{SCI}=(1 \times \text { single crack })+(3 \times \text { double crack })+(5 \times \text { multiple crack })+\cdots
$$

\subsection{Data Analysis}

The experiment was conducted in a complete randomized design and data obtained were subjected to analysis of variance (ANOVA) using GenStat statistical
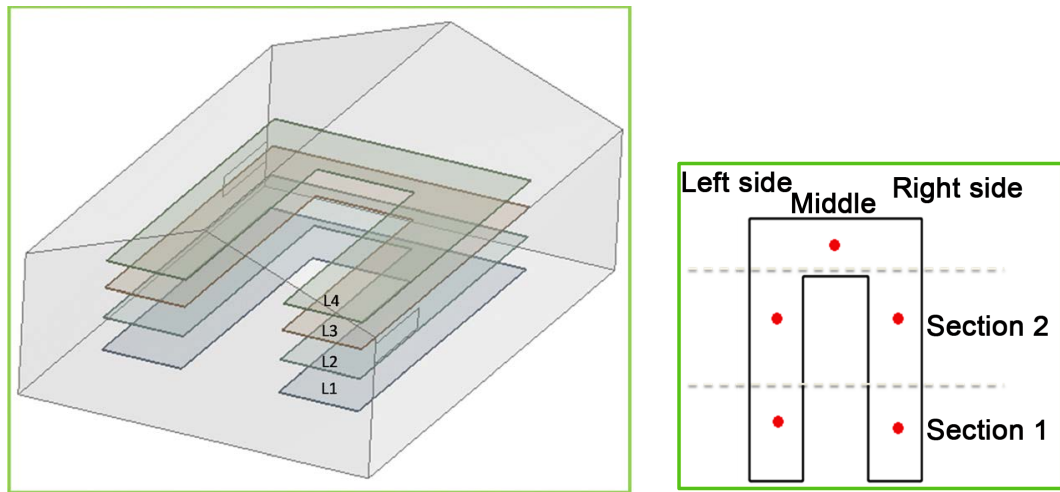

Figure 2. Drying levels and data logging positions in the dryer. 
software version 12 at a significance level of $5 \%(\mathrm{p} \leq 0.05)$. Results were presented in tables and graphs using Microsoft Excel using the mean values obtained.

\section{Results}

\subsection{Temperature Variations during Drying}

The temperature profile recorded during the drying of the maize grains for seed in the SBHD is presented in Figure 3. Drying air temperature at level 4, increased during the first four hours, from $41.1^{\circ} \mathrm{C}$ to a maximum of $58.9^{\circ} \mathrm{C}$ by noon and reduced to $43.2^{\circ} \mathrm{C}$ at the end of the drying process. Over the drying period of 7 hours, a mean temperature of $52.8^{\circ} \mathrm{C} \pm 5.4^{\circ} \mathrm{C}$ was recorded at $\mathrm{L} 4$. Similar variations in temperature were observed for L3, L2 and L1 in the dryer with mean temperatures of $49.8^{\circ} \mathrm{C} \pm 5.6^{\circ} \mathrm{C}, 45.4^{\circ} \mathrm{C} \pm 5^{\circ} \mathrm{C}$ and $44.4^{\circ} \mathrm{C} \pm 4.6^{\circ} \mathrm{C}$, respectively. Comparably, the overall mean temperature inside the dryer (L1-L4) of $48.1^{\circ} \mathrm{C}$ was higher than the ambient temperature by $12^{\circ} \mathrm{C}$. This stratification was attributed to the solar insolation during the time of the experiment as suggested by [17]. Additionally, hot air from the furnace rises due to forced convection with the heat accumulating at the upmost levels of the dryer leading to higher temperatures at L4.

\subsection{Changes in Maize Grain Moisture Content during Drying}

As the drying temperatures increased, the moisture content of the maize grains reduced. Maize grains at $22.8 \%$ moisture content were dried to an overall final average moisture content of $12.8 \% \pm 0.2 \%$ (wb) within $7 \mathrm{hrs}$. However, samples at L4 and L3 reached average moisture content of $13 \%$ within 5 and $6 \mathrm{hrs}$ of drying, respectively, while samples at L1 and L2 reached final moisture content of $12.7 \%$ by the $7^{\text {th }}$ hour. Comparably, samples dried in the sun reduced from $22.8 \%$ to $12.9 \%$ in $7 \mathrm{hrs}$. The result showed that overall drying rates of $1.3 \% / \mathrm{hr}$ were achieved in the dryer compared to $1.2 \% / \mathrm{hr}$ for samples dried in the open sun. The high moisture reduction rate achieved in the dryer could be attributed

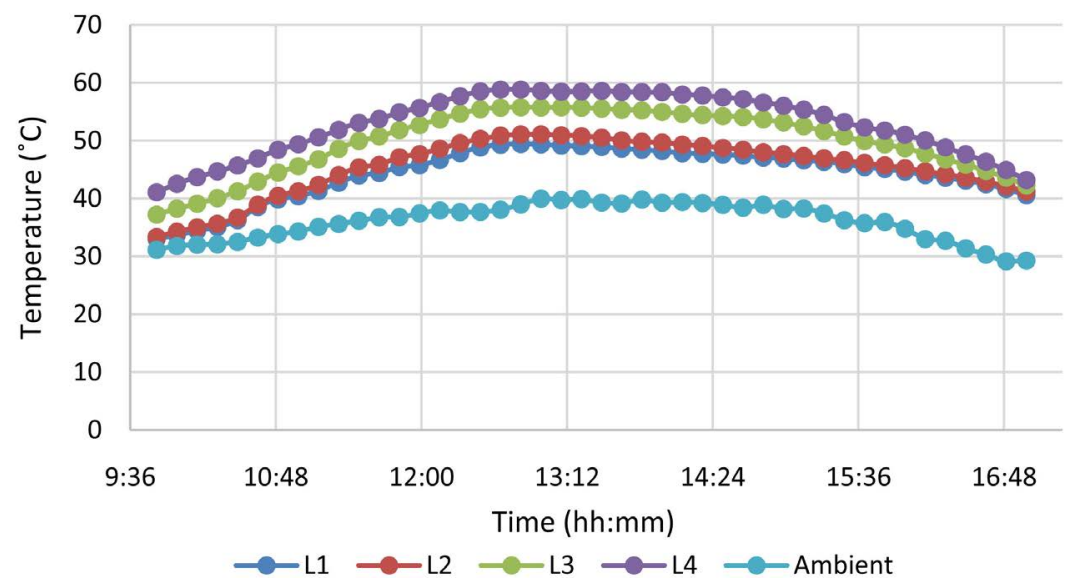

Figure 3. Temperature trend at different levels in the SBHD vs ambient. 
to the additional heat from the biomass furnace attached to the dryer which facilitated the faster drying of grains to the required moisture content. Figure 4 shows the variation of moisture content of maize samples dried at different levels in the SBHD as compared to the samples dried in the open sun.

\subsection{Effect of Drying Temperature in SBHD on Maize Germination}

Drying maize using the SBHD did not significantly reduce the viability of the kernels. However, there was a $9 \%$ reduction in overall germination potential of grains dried in the SHBD compared to grains dried in the open sun. From the temperature effect, it was observed that, due to the increase in temperature of drying air at the upper level (L4), the percentage of kernel viability decreased compared to the lower levels (Table 1 ). Germination rate of grains dried at various levels with mean temperatures of $52.8^{\circ} \mathrm{C}, 49.8^{\circ} \mathrm{C}, 45.4^{\circ} \mathrm{C}$ and $44.4^{\circ} \mathrm{C}$ were $44 \%, 61 \%, 64 \%$, and 77\%, respectively (Table 1). In comparison, the mean temperature and germination rate for maize dried in the open sun was $36^{\circ} \mathrm{C}$ and $71 \%$, respectively.

\subsection{Stress Crack Analysis}

Percent stress-cracked kernels in different categories for maize grains dried at the various levels in the SBHD are presented in Table 2. It was observed that there was much variation among the different stress-crack categories for grains

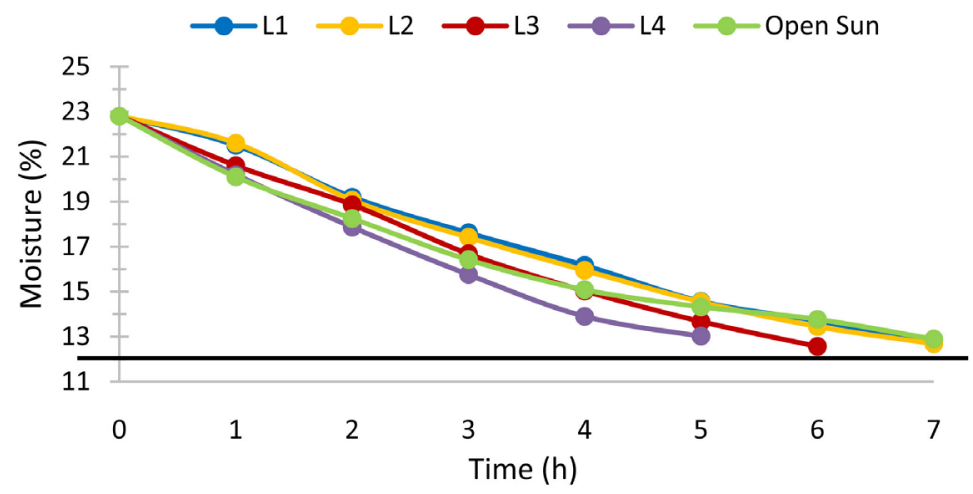

Figure 4. Moisture content across levels in the SBHD vs open sun.

Table 1. Percentage germination of maize dried using SBHD*.

\begin{tabular}{ccc}
\hline Layer & Mean temperature $\left({ }^{\circ} \mathrm{C}\right)$ & Germination (\%) \\
\hline Level 4 & $52.8 \pm 5.4$ & $44 \mathrm{c}$ \\
Level 3 & $49.8 \pm 5.6$ & $61 \mathrm{~b}$ \\
Level 2 & $45.4 \pm 5.0$ & $64 \mathrm{~b}$ \\
Level 1 & $44.4 \pm 4.6$ & $77 \mathrm{a}$ \\
Open Sun & $35.99 \pm 3.2$ & $71 \mathrm{ab}$ \\
LSD (p $\leq 0.05)$ & & 11.95 \\
\hline
\end{tabular}

${ }^{\star}$ Mean values followed by same letter in a column are not significantly different $(\mathrm{P}>0.05)$. 
Table 2. Stress crack analysis of sampled maize at different levels.

\begin{tabular}{ccccccc}
\hline \multirow{2}{*}{ Level } & Temp. $\left({ }^{\circ} \mathrm{C}\right)$ & \multicolumn{5}{c}{ Stress Crack Categories } \\
\cline { 3 - 6 } & & Undamaged (\%) & Single (\%) & Double (\%) & Multiple (\%) & SCI \\
\hline Level 1 & $44.4 \pm 4.6$ & 90 & 5 & 4 & 1 & 22 \\
Level 2 & $45.4 \pm 5.0$ & 90 & 4 & 5 & 1 & 24 \\
Level 3 & $49.8 \pm 5.6$ & 68 & 18 & 9 & 5 & 70 \\
Level 4 & $52.8 \pm 5.4$ & 38 & 26 & 23 & 13 & 160 \\
Open Sun & $35.99 \pm 3.2$ & 94 & 2 & 4 & 0 & 14 \\
\hline
\end{tabular}

dried at the different levels in the dryer. In all categories, grains dried at level 4 (L4), had higher stress crack values compared to grains dried at L3, L2, L1 and the open sun. Among the stress-crack categories, the percentage multiple stress cracks were the lowest at all the levels followed by the doubles and the singles in that order. To establish variations in drying temperature effect on the quality of the grains, the SCI was determined for grains dried at the various levels. It was revealed that, temperature had an effect on the final quality of the dried maize in terms of the kernels susceptibility to damage or breakage. As shown in Table 2, the highest SCI of 160 was recorded for Level 4 followed by L3, L2, L1 and the open sun with SCI of 70, 24, 22 and 14, respectively. The outlier of the SCI at L4 can be attributed to the higher temperatures recorded at the level and indicates a high susceptibility to damage or breakage of grains at L4.

\section{Discussions}

\subsection{Temperature Trend in Solar Biomass Hybrid Dryer}

The results revealed that drying temperatures in the SBHD increased from bottom (L1) across the upper levels (L2, L3 and L4) of the drying shelfs/racks. A mean drying temperature of $44.4^{\circ} \mathrm{C}$ was recorded at $\mathrm{L} 1$ while a mean temperature of $52.8^{\circ} \mathrm{C}$ was recorded at L4. Comparably, the mean open-sun drying temperature of $35.99^{\circ} \mathrm{C}$ was recorded during the same period. The high temperatures recorded in the dryer compared to the open-sun temperature could be attributed to the heat build-up in the dryer due to the transparent cover material used to construct the SBHD. As reported by [10], the transparent cover material allows direct solar insolation to occur and can prevent heat from escaping by acting as a heat trap for infrared (thermal) radiation thereby confining the heated air. The increasing trend in temperature from L1 to L4 could also be attributed to the air density differences due the buoyancy effect which caused stratification of hot and cooler air. The closeness of the top drying shelves to the roof where the hot air is accumulated beneath and recirculated in the dryer may also have contributed to the increasing trend. Similar results were obtained by [18] during maize drying in a solar cabinet dryer. The burning of maize cobs in the biomass furnace also contributed to the high temperature trend in the dryer compared to the ambient temperature agreeing with the findings of [13]. 


\subsection{Effect of Drying Temperature on Moisture Loss, Kernel Damage and Viability}

As drying temperature increased from the bottom to upper drying shelves (L1 L4) in the SBHD, grain moisture content decreased. Mean moisture content decrease steadily from $22.8 \%$ to $12.8 \%$ (wb) within 7 hours of drying. In a similar work by [13], maize cobs dried in a biomass natural convection dryer had its moisture content reduced to $14 \%$ between 5 and 6 hours of drying. Similar results were also obtained for the drying of beans as reported by [19], and coroba slices by [20]. The final moisture content of the dried maize grains was close to $13 \%$. This according to [21] is appropriate for seed storage and may prevent mould growth and preserve seed quality in seed production.

The effect of drying conditions on grain quality was demonstrated using a damage index (DI) as reported by [22]. The results as presented in Table 2 showed that there was a correlation between kernel stress crack formation and drying temperature. An increase in drying temperature across the drying shelves resulted in an increase in stress cracks on maize kernels. This is corroborated by [23] who reported of increased damage index as drying temperature increased above $75^{\circ} \mathrm{C}$ during drying of a corn variety named SC- 10 .

In this study, the drying temperature with the lowest stress crack index was $35.99^{\circ} \mathrm{C} \pm 3.2^{\circ} \mathrm{C}$ for kernels dried in the open-sun. Comparatively, similar results were observed for kernels dried at the lower levels (L1 - L3) though there was an overall temperature increase in the dryer compared to the open-sun. The reduction in stress crack index at the lower levels could be attributed to lower temperatures and the overcast created by the drying shelf above, L4, which shielded the lower levels from direct solar insolation on the kernels. However, the percentage damage of kernels in the single, double and multiple cracking categories increased significantly for kernels dried at L4 (Table 2) with the highest recorded stress crack index of 160.The direct exposure of the kernels and the maximum grain temperatures reached in the dryer at the top trays (L4) may have contributed to this occurrence. Similar works by [24] and [25] showed similar results where an increase in drying temperature increased moisture gradient, creating internal tensions, cracks, breakages, and fractures in dried maize. Damage and fractures which results in cracks in the structure of agricultural products due the creation of internal stresses has also been reported by [26].

Germination of dried maize kernels was affected by drying temperature in the SBHD. Evaluation of maize germination performance established the negative effects of increase in drying temperature on the physiological quality of maize seeds. An increase in drying temperature from the bottom to the upper drying shelves (L1 - L4) resulted in decreases in kernel germination. Maize kernels dried at the upper tray (L4) of the SBHD where the highest mean temperature (52.8) and highest SCI (160) were recorded had the lowest kernel germination (44\%). Similar observation was made by others in evaluation of sweet sorghum seeds in which a reduction in germination was recorded, especially at temperatures above $40^{\circ} \mathrm{C}$ [27]. The low germination rate observed at $\mathrm{L} 4$ could be attri- 
buted to the high drying temperature, which resulted in the formation of stress cracks in the seed coat and microfissures in the cotyledons as suggested by [28] and [29].

Viability of maize kernels dried at the lower levels (L1 - L3) were not significantly affected by the drying air temperature. Kernels dried at L1 - L3 showed a germination range $(61 \%-77 \%)$, compared to kernels dried at the upper tray (44\%). However, improvement in the drying process can help achieve the required 90\% recommended by the Ghana Certified Seed Producers Association. Overall, lower drying temperatures at the lower levels (L1 - L3) resulted in increased germination by $33 \%$. Similar observations were made by [13], who reported that, drying maize using a biomass-heated convection dryer did not significantly reduce germination potential. Also [19] reported that, grain dried using the natural solar convection dryer technology is also good for seed production.

\section{Conclusions}

The suitability of the solar biomass hybrid dryer for maize for commercial production of seed maize was investigated. The chronological change of physical characteristics of maize grain as affected by drying temperature in the dryer was studied. Results showed that there was a correlation between drying temperature, damage index and maize kernel viability. Kernel damage and germination were significantly affected at the upper drying section (L4) of the dryer as the drying air temperature increased. However, the optimum drying temperature $\left(<50^{\circ} \mathrm{C}\right)$ achieved at the lower levels (L1 - L3) of the dryer did not significantly affect the final quality of dried kernels and increased germination by $33 \%$ compared to kernels dried at L4.

Finally, the local manufacture of the solar biomass hybrid dryer will not only provide assurance to commercial maize seed producers but also maize traders, farmers, aggregators and poultry feed producers, who can all benefit from the dryer as a better alternative to the traditional open-sun drying method which is weather dependent and not hygienic.

\section{Acknowledgements}

The authors express sincere appreciation to USDA Foreign Agricultural Service for provided funding for this project under its Scientific Cooperation Research Program Agreement SR-CR-16-001.The use of trade, firm, or corporation names in this publication is for the information and convenience of the reader. Such use does not constitute an official endorsement or approval by the United States Department of Agriculture or the Agricultural Research Service of any product or service to the exclusion of others that may be suitable.

\section{Conflicts of Interest}

The authors declare no conflicts of interest regarding the publication of this paper. 


\section{References}

[1] Amanor-Boadu, V. (2012) Maize Price Trends in Ghana (2007-2011). METSSGhana Research and Issue Paper Series No. 01.

[2] Ministry of Food and Agriculture (MoFA) (2013) Agriculture in Ghana, Facts and Figures by Statistical Research and Information Department of MoFA.

http://mofa.gov.gh/site/?page_id=6032

[3] Etwire, P.M., Atokple, I.D., Buah, S.S., Abdulai, A.L., Karikari, A.S. and Asungre, P. (2013) Analysis of the Seed System in Ghana. International Journal of Advance Agricultural Research, 1, 7-13.

[4] Carvalho, E.R., Oliveira, J.A., Mavaieie, D.P.R., Silva, H.W. and Lopes, C.G.M. (2016) Pre-Packing Cooling and Types of Packages in Maintaining Physiological Quality of Soybean Seeds during Storage. Journal of Seed Science, 38, 129-139. https://doi.org/10.1590/2317-1545v38n2158956

[5] Akowuah, J.O., Mensah, L.D., Chan, C. and Roskilly, A. (2015) Effects of Practices of Maize Farmers and Traders in Ghana on Contamination of Maize by Aflatoxins: Case Study of Ejura-Sekyeredumase Municipality. African Journal of Microbiology Research, 9, 1658-1666. https://doi.org/10.5897/AJMR2014.7293

[6] Folaranmi, J. (2008) Design, Construction and Testing of Simple Solar Maize Dryer. Leonardo Electronic Journal of Practices and Technologies, 13, 122-130.

[7] Togrul, I.T. and Pehlivan, D. (2004) Modelling of Thin Layer Drying Kinetics of Some Fruits under Open-Air Sun Drying Process. Journal of Food Engineering, 65, 413-425. https://doi.org/10.1016/j.jfoodeng.2004.02.001

[8] Weiss, W. and Buchinger, J. (2015) Solar Drying. http://www.aee-intec.at/0uploads/dateien553.pdf

[9] Hassan, M.M. (2010) Drying and Quality Evaluation of Paddy Seeds in Hybrid Dryer. www.saulibrary.edu.bd/daatj/public/index.php/.../BAU201001_14-fm_5.pdf

[10] Tonui, K.S., Mutai, E.B.K., Mutuli, D.A., Mbuge, D.O. and Too K.V. (2014) Design and Evaluation of Solar Grain Dryer with a Back-Up Heater. Research Journal of Applied Sciences, Engineering and Technology, 7, 3036-3043. https://doi.org/10.19026/rjaset.7.639

[11] Sekyere, C.K.K., Forson, F.K. and Adam, F.W. (2016) Experimental Investigation of the Drying Characteristics of a Mixed Mode Natural Convection Solar Crop Dryer with Back up Heater. Renewable Energy, 92, 532-542.

[12] Gatea, A.A. (2011) Performance Evaluation of a Mixed Mode Solar Dryer for Evaporating Moisture in Beans. Journal of Agricultural Biotechnology and Sustainable Development, 3, 65-71.

[13] Kaaya, A.N. and Kyamuhangire, W. (2010) Drying Maize in Using Biomass-Heated Natural Convection Dryer to Improve Grain Quality during Storage. Journal of Applied Sciences, 10, 967-974. https://doi.org/10.3923/jas.2010.967.974

[14] International Seed Testing Association (1985) International Rules for Seed Testing 1985. Seed Science and Technology, 13, 299-520.

[15] Azadi, M.S. and Younesi, E. (2013) The Effect of Storage on Germination Characteristic and Enzyme Activity of Sorghum Seed. Journal of Stress Physiology \& Biochemistry, 9, 289-298.

[16] Kirleis, A.W. and Stroshine, R.L. (1990) Effects of Hardness and Drying Air Temperature on Breakage Susceptibility and Dry-Milling Characteristics of Yellow Dent Corn. Cereal Chemistry, 67, 523-528.

[17] Tibebu, T.B., Obeng, G.Y., Mensah, E. and Smith, A. (2015) Solar Dryer with Bio- 
mass Backup Heater for Drying Fruits: Development and Performance Analysis. Journal of Science and Technology, 36, 10-25.

[18] Achint, S., Ambrose, R.P.K. and Maier, D. (2017) CFD Simulation of Corn Drying in a Natural Convection Solar Dryer. Drying Technology, 36, 859-870.

[19] Agona, J.A. and Nahdy, S.M. (1998) Effect of Solar Drying Period of Beans on Seed Viability, Cooking Time and Injuriousness of Acanthoscelides obtectus Say. African Crop Science Journal, 6, 417-421. https://doi.org/10.4314/acsj.v6i4.27793

[20] Corzo, O., Bracho, N., Vasquez, A. and Pereira, A. (2010) Determination of Suitable Thin Layer Model for Air Drying of Coroba Slices (Atteleamaripa) at Different Air Temperatures and Velocities. Journal of Food Processing and Preservation, 34, 587-598. https://doi.org/10.1111/j.1745-4549.2009.00377.x

[21] Dubale, B., Solomon, A., Geremew, B., Sethumadhava, R. and Waktole, S. (2014) Mycoflora of Grain Maize (Zea mays L.) Stored in Traditional Storage Containers (Gombisa and Sacks) in Selected Woredas of Jimma Zone, Ethiopia. African Journal of Food, Agriculture, Nutrition and Development, 14, 1-19.

[22] Shoughy, M.I., Marey, S.A. and El-Shenawy, A.A. (2009) Effect of Drying Temperatures on Stress Cracks and Breakage Susceptibility of Corn Grains. Misr Journal of Agricultural Engineering, 26, 453-468.

[23] Watkins, A.E. and Maier, D.E. (2001) Thin-Layer Drying Rates, Stress Cracking, and Digestibility of Selected High-Oil Corn Hybrids. Transactions of the ASAE, 44, 617-622. https://doi.org/10.13031/2013.6088

[24] Lewicki, P.P. and Pawlak, G. (2003) Effect of Drying on Microstructure of Plant Tissue. Drying Technology, 21, 657-683. https://doi.org/10.1081/DRT-120019057

[25] Sadjad, A. and Saeid, M. (2014) Effect of Drying Temperature on Mechanical Properties of Dried Corn. Drying Technology: An International Journal, 32, 774-780. https://doi.org/10.1080/07373937.2013.845203

[26] Chakraverty, A. (1988) Post-Harvest Technology of Cereals, Pulses and Oilseeds. Oxford \& IBH Pub. Co., New Delhi.

[27] Ullmann, R., Resende, O., Chaves, T.H., Oliveira, D.E.C. and Costa, L.M. (2015) Physiological Quality of Sorghum Seeds Subjected to Drying under Different Air Conditions. Brazilian Journal of Agricultural and Environmental Engineering, 19, 64-69.

[28] Afrakhteh, S., Frahmandfar, E., Hamidi, A. and Ramandi, H.D. (2013) Evaluation of Growth Characteristics and Seedling Vigor in Two Cultivars of Soybean Dried under Different Temperature and Fluidized Bed Dryer. International Journal of Agriculture and Crop Sciences, 5, 2537-2544. https://www.researchgate.net/publication/306018055

[29] Menezes, N.L., Cicero, S.M., Villela, F.A. and Bortolotto, R.P. (2012) Using X-Rays to Evaluate Fissures in Rice Seeds Dried Artificially. Revista Brasileira de Sementes, 34, 70-77. http://www.scielo.br/pdf/rbs/v34n1/a09v34n1.pdf https://doi.org/10.1590/S0101-31222012000100009 